\title{
PRESCHOOL EDUCATION AND INSPECTION PROCESS IN TURKEY
}

\begin{abstract}
Preschool education is characterized as the magic year of life. 14th National Education Council defined preschool education as the education process for the development levels and individual characteristics of the children in 0-72 month group, provides them environment opportunities with rich stimulants, supports their physical, mental, emotional and social developments, guides them in the direction of the cultural values of society and prepares them for the primary education. Inspection is the work that evaluates educational activities and also prepares the more effective environment and conditions. This research analyzed the documents relating to preschool education and inspection in Turkey by a documental scanning method. The current problems were revealed by the suggestions developed.
\end{abstract}

\section{keywords}

Preschool Education, Educational Inspection.

\section{Türkiye'de Okulöncesi Eğitim ve Denetim Süreci}

öz

Yaşamın sihirli yılları olarak nitelendirilen okulöncesi eğitim; ülkemizde 14. Milli Eğitim Şura'sında; 0-72 ay grubundaki çocukların; gelişim düzeylerine ve bireysel özelliklerine uygun, zengin uyarıcı ve çevre imkânları sağlayan, bedensel, zi- 
hinsel duygusal ve sosyal yönden gelişmelerini destekleyen, toplumun kültürel değerleri doğrultusunda en iyi biçimde yönlendiren, ilkokula hazırlayan, temel eğitim bütünlüğü içerisinde yer alan eğitim süreci olarak tanımlanmıştır. Denetim ise; eğitim öğretim etkinliklerinin değerlendirilmesi ve daha etkili ortam ve koşullarının hazırlanması işidir. Bu çalışmada belgesel tarama yöntemiyle Türkiye'deki Okul öncesi eğitim ve denetimine ilişkin dokümanlar incelenmiş, var olan sorunlar, geliştirilen önerilerle ortaya konulmuştur.

\section{anahtar kelimeler}

Okulöncesi eğitim, eğitim denetimi.

\section{Introduction}

The Turkish education system is organized by predicating Turkish constitution, Laws Regulating Education, Government Programs, Development Plans and National Education Councils on. Principles of education provide education to be republican, secular, scientific, general and equal, functional and modern. The Turkish education system is democratic, modern, scientific, secular and coeducation. Purpose of this related system is to increase the welfare and happiness of Turkish citizens; support and accelerate economic, social and cultural development; make the Turkish Nation is an excellent and creative partner of contemporary civilization. A secular education system that is based on principles of the republic was organized by 789 numbered law on 22 March 1926. Modern education stages were specified besides several new and modern arrangements. The goal of social upheaval process that started by the establishment of the republic is to take a modern turn for traditional social structure; bring modern citizen consciousness; constitute social structure via education.

\section{General Purposes of Turkish Education System}

The general purpose of Turkish National Education is to raise citizens who adopt Atatürk Nationalism, the sentimental and cultural value of Turkish nation; love and aggrandize his/her family and country; know duties and responsibilities to the Turkish Republic. Besides, raising citizens who have a balanced and healthy character, free and scientific mental power, a broad worldview; value to privateness and enterprise; bear responsibility for society; are creative and productive are also the purposes of Turkish National Education. One of the general purposes of Turkish education is to prepare citizens for life by bringing them required information, skill, and behaviors; provide them to have a profession so as to contribute to the happiness of society. 
Thus, Turkish National Education increases the welfare and peace of Turkish citizens and supports and accelerates economic, social and cultural development (MNE, 2001: 3).

\section{Special Purposes of Turkish National Education}

Special purposes of the Turkish education system are organized so as to actualize the general purposes. Special purposes of different types of educational establishments are arranged based on the general purposes and fundamental principles.Principles of Turkish National Education are as follows; Generality and equality; the right to education; equality in opportunity; continuity; Ataturk's principles and reforms; democracy education; secularism; scientificness; being planned; coeducation; collaboration between school and family; education anywhere (MNE, 2001: 3-4).

\section{Legal Foundations of Inspection in the Turkish Education System}

With reference to the $42 \mathrm{nd}$ article of our constitution Education is conducted under the observation and control of the government based on modern science and training principles in line with Ataturk's principles and reforms. It is emphasized in the 56th article of 1739 numbered National Education Basic Law that Ministry of National Education is responsible for conducting, observing and inspecting education services on behalf of the state. Presidency of Supervisory Board took place among counseling and inspection units in the 26th article of 3797 numbered Organization and Duties of Ministry of National Education Law. The 27th article of related law mentioned the duties of Presidency of Supervisory Board. There is the provision on the 53rd article of related law called "Provincial Organization" that "Presidency of Primary Education Inspectors" is established within Provincial Directorates for National Education".

There are "Presidency of Supervisory Board" in the central organization and "Presidency of Primary Education Inspectors" in the provincial organization based on 26th, 27th and 53rd articles of 3797 numbered code.

Counseling, research and inspection works of school and institutions that are attached to the Ministry of National Education are conducted by 28/01/1997 dated and 97/9192 numbered Ministry of National Education Supervisory Board Regulation; 03/10/1993 dated and 21717 numbered Ministry of National Education Supervisory Board Legislation; 13/08/1999 dated and 23785 numbered Ministry of National Education Presidency of Primary Education 
Inspectors Regulation; 01/02/2001 dated and 1323 numbered Ministry of National Education Presidency of Primary Education Inspectors Counseling and Inspection Guide.

Organizational Structure and Operation of Inspection Subsystem in Turkish Education System

Administrative supervision of institutions and organizations is conducted by inspection organizations in principle. Hierarchical inspection mandate of minister or executive in organizations like ministries and general directorates covers the whole organization. Under this circumstance, it is impossible for top executives to perform inspection duties in person.With reference to 3046 numbered Law on Establishment and Duty Principles of Ministries "There are inspectors and a Ministry Supervisory Board attached to the top executive of the organization in each of the ministries, public institute (Gözübüyük, 1999: 77).Ministry of National Education Supervisory Board and Inspectors can be given as an example of the related situation (Karakulak, 1992: 4).Ministry Supervisory Committees are responsible for enlightening the minister about each kind of activity and conducting inspection and research works of ministry organization and related institutions attached to the ministry (Eryılmaz, 1995: 308).

Ministry of National Education Presidency of Supervisory Board Supervisory Board is composed of a president, lead inspector, inspector and inspector assistants. The board is directly attached to the minister; the center of the board is Ankara. Work centers and offices can be established out of Ankara by the offer of president and confirmation of the minister. Those work centers and offices can be removed or relocated in the same way.Senior inspectors in work centers are responsible for fulfilling the orders of board president; conducting office services; organizing the relationships between inspectors and office; providing a compatible working order among the inspectors (MNE Supervisory Board Regulation, Article 3-4; MNE Supervisory Board Regulation, Article 5-6).

\section{Ministry of National Education Department of Primary Education Inspectors}

With reference to a 27th article of August 13, 1999 dated and 23785 numbered MNE Department of Primary Education Inspectors "Department of Primary Education Inspectors that is composed of a president, vice president, inspector, 
inspector assistants to conduct counseling, inspection and assessment works based on directorates of national education in each of the provinces. There are research and assessment commissions within presidency.Again, inspection groups with inspector and inspector assistants are constituted in provinces; inspection groups are divided into the subgroups. There is an inspector from each branch in inspector groups.

\section{Preschool Education and Inspection in Turkey}

There are several legislative regulations toward establishing, organizing and conducting pre-school education institutions in Turkey. In this chapter, current legal foundations can be seen by the historical process

\section{The Constitution of the Republic of Turkey}

Below articles about pre-school education are as follows; Article 41: Family is the foundation of Turkish Society. State takes required precautions to be protected especially the mother and children and applied family planning (Arslan, 2001: 43). Article 42: Nobody can be starved of the right to education. The scope of the right to education is specified and organized by the law. Education is conducted under observation and control of the state based on modern science and education principles in line with Ataturk's principles and reforms. The educational organization must not be established inconsistently with these principles. Primary education is mandatory for all citizens without noticing gender; education is free in public schools (Arslan, 2001:44). Article 59: State takes precautions that improve the physical and mental health of Turkish citizens from all ages and also encourages society to play sports (Arslan, 2001: 53);

Article 62: State takes required precautions to meet educational and cultural needs and provide social insurance of Turkish people who work in abroad. Besides, the state also takes precautions to help them while returning to the homeland (Arslan, 2001: 54-55).

\section{7 numbered Civil Servants Law}

57 numbered Civil Servants Law came into force on July 23, 1965; there was made an amendment by November 29, 1984, dated and 243/29 numbered delegated legislation Article 191: Nurseries and social foundations can be constituted in required places for civil servants. Establishment and working principles of those places are specified by the general regulation of State Personnel Presidency and Finance Ministry (Pazarcl, 1996: 125). Regulation on 
Nurseries that are established by state institutions and organizations specify the basis and procedures relating to working and inspection of nurseries (Official Gazette, 1965: 11).

\section{5 numbered Private Schools Law}

625 numbered and June 18, 1965, dated Private Schools law was amended by 2843, 3035 and 3236 numbered codes. Article 1: This law (after 3035 numbered amendment) includes provisions about pre-school, primary education and secondary education institutions that are established by Turkish real persons, private person; opening various courses, private teaching institutions, etude centers, tailoring schools and similar organizations (MNE, 2000: 226). Article 2: Private educational institutions are under the observation and inspection of the Ministry of National Education. These institutions cannot organize their activity only for making a gain. However, they can derive a profit to increase the quality of education in line with the purposes of Turkish National Education. Private kindergartens (3035 numbered Law), preschools and vocational schools are free of company and income tax as from the date when they start to education. Other required conditions for institution opening permission are mentioned in regulation (MNE, 2000: 226)

\section{2 numbered Primary Education and Training Law}

222 numbered Primary Education and Training Law was accepted on January 5, 1961. Article 6: Primary education institutions are divided into two; optional ones and obligatory ones (MNE, 2000: 121). Article 13: Children who reach the age of compulsory education are trained in pre-school institutions. These related institutions can be established by real and legal persons, municipalities, local governments, and state (MEB, 2000, p. 122).

\section{9 numbered National Education Basic Law}

1739 numbered National Education Basic Law was accepted on June 24, 1973. Article 18: Turkish National Education is composed of two main groups as formal education and non-formal education. Formal training includes pre-school education, primary education, secondary education and higher education institutions (MNE, 2000: 195); Article 19: Pre-school education includes education of children who do not reach compulsory primary education age (MNE, 2000: 196). Article 20: Purpose and duties of pre-school education are to provide children to physically and emotionally develop and prepare the to primary education. Besides, pre-school education creates a common growth 
environment for children come from incapable circles and families; provides children to speak Turkish fluently (MNE, 2000: 196)

\section{8 numbered Law on Social Services and Child Protection Institution}

2828 numbered Law on Social Services and Child Protection Institution came into force on May 27, 1983. Article 3: Daily children's home is the social service organizations that are established to raise children in 0-6 age group and also protect and develop physical and mental health of children in the same age group (YIlmaz, 1999: 58)

\section{7 numbered Law on Organization and Duties of Ministry of National Education}

3797 numbered Law on Organization and Duties of Ministry of National Education came into force on April 30, 1992. Article 9: Main service units of the Ministry of National Education are as follows; Article 10: Duties of General Directorate of Pre-school Education are as follows; conducting all duty and services about education and management of school and institutions of children who do not reach the age of compulsory primary education; preparing curriculum and educational equipment and submitting to Turkish Education Board (MNE, 2000: 179-180).

\section{3 numbered Delegated Legislation on Special Education}

Delegated Legislation on Special Education that came into force on June 06, 1997 was assigned by Council of Ministers on May 30, 1997, by the power of December 03, 1996 dated and 4216 numbered law about the handicapped. Article 6: Special education services are continued in houses and institutions based on informing and supporting the family who has a child in early childhood. Article 7: Pre-school education is compulsory for children who need special education. This related education is given in special education schools and other pre-school educational establishments. Duration of preschool education of children can be extended by considering developmental and individual characteristics (MNE, 2000: 362).

\section{7 numbered Labor Act}

4857 numbered Labor Act came into force on June 10, 2003, by being accepted on May 22, 2003 (25134 numbered official gazette). Article 88: The issues such as the periods when pregnant and breastfeeding women cannot be worked; basis and procedures these related women need to obey in unexceptionable 
works to work; conditions to establish lactation rooms and child care rooms are mentioned in the regulation of the Ministry of Labor and Social Security (www.calisma.gov.dr/mevzuat).

\section{Pre-school Education Institutions}

Pre-school education period is called as the period that takes the time from birth and primary education; pre-school education institution is called as all public and private educational establishments for children who are in preschool age (MNETD, 2002 Mart: 146).In our country, preschool education is given in public and private preschools of the Ministry of National Education; primary schools; practice classes in girls' vocational high schools; public and private kindergartens, day nurseries and nurseries of Social Services and Child Protection Institution (Commission, 1993: 2-3)Kindergartens: Institutions and organizations give service towards care and education of children in the 24 age group. Daily Children's Home: Institutions and organizations that aim education besides healthy growth and care of children in the 0-6 age group are attached to Social Services and Child Protection Institution. Private Daily Children's Home: Institutions and organizations that are established by a private person and organizations aim education besides healthy growth and care of children in 0-6 age group (Official Gazette, 1986, 22781: 11).

Day nursery: Pre-school institution that is attached to the Ministry of National Education and established for the education of children in 36-72 months group. Kindergarten: Pre-school institution that is opened within primary schools and primary education for the education of children 60-72 group. Application class: Pre-school institution within girls' vocational school for the education of 36-72 months group. Private Turkish Kindergarten: Preschool institution that provides training for children in 36-72 months group and is established based on 625 numbered Law on Private Schools. Private Foreign Kindergarten: Pre-school institution that provides training for children in 36-72 months group and is established by foreign nationals. Private Kindergarten of Minorities: It is an institution that provides pre-school education for minorities' children in 36-72 months group (MNE, Commission, 1993: 3-4; MNE, Journal of Notices, 65, 2534 (March 2002): 146).

\section{Purposes of Pre-school Education}

Duties and purposes of pre-school education are as follows;

Providing children physically, mentally, emotionally develop and gain good habits, 
Bringing skills for communicating and thinking in a creative way,

Providing children to speak Turkish fluently,

Creating a common growth environment for children come from incapable circle and families,

Preparing children to primary education (MNE, Journal of Notices, 65, 2534 (March 2002):147; National Education Basic Law (1739 S.K.), 1973, art.5; Primary Education and Training Law (222 S.K.) art.6)

\section{Principles of Primary Education}

Pre-school period is the basis of life. Learning rate is so high in the related period. General development characteristics of each of the age groups are common. Pre-school education is based on some specific principles. Related principles are as follows;

- Education environment that can support physical, mental and emotional development of children is prepared.

- Ages, developmental features, learning rates, interests and requirements of children are considered while the educational activities are organized.

- It is provided that children gain healthy and good habits besides being sensitive to the environment.

- Educational activities are in characteristics that can develop feelings of participation, responsibility, cooperation, and sharing of children.

- It is aimed to raise children who adopt humanity and love of Atatürk, homeland, nation, flag, family; believe in himself/herself; knows rights and responsibilities.

- It is conducted in love and compassion approach. Children are treated equally and individual characteristics are taken into account. Penalty or pressure are not imposed and there are no restrictions.

- It is determined that whether the goals are achieved. These results are considered while making a plan (MNE, Journal of Notices, 65, 2534 (March 2002): 147).

\section{Working Principles in Pre-school Education Institutions}

Regulation on Pre-school Education Institutions was prepared based on 1739 numbered National Education Basic Law, 222 numbered Primary Education Law, 3797 numbered Law on Organization and Duties of Ministry of National 
Education, 625 numbered Law on Private Schools and 573 numbered Delegated Legislation on Private Education.

It is essential to perform full-time schooling in pre-schools and application classes. However, there can also be performed halftime schooling by considering the physical situation of schools and demands of parents.

There is conducted halftime or dual education in pre-schools without noticing the education style of the school they are attached to.

Duration of the year of study is at least 180 weekdays in pre-school education institutions. Starting and end time of daily education is determined by governorships.

The teacher does activities for eight hours in preschools and application classes; 6 hours in nursery classes.

It is essential to perform nonstop education in pre-school education institutions; there is no playtime. One training time is $\mathbf{5 0}$ minutes.

It is essential that the number of children in a group must not be more than 20. If the number of children is more than 20 , the second group is formed. A number of children can be increased to 25 in single nursery classes and application classes by considering the class capacity (MNE, Journal of notices, 65, 2534 (March 2002):147-148).

\section{Development of Pre-school Education Process in Turkey}

Since our country has an ever-developing structure, we are in a period of change. Economic and social changes bring new needs and values and cause changes in community life. Pre-school education in Turkey has made almost the same level of progress with western countries (Oktay, 2002: 78).There were organizations that undertook the education of children before establishing pre-school educations in Turkey (Oktay, 2002: 79)Infants' school that was opened in Sultan Fatih period in Ottoman Empire is known as the start of the preschools. Parents sent their children in those institutions for playing games and moving away from the home (Oktay, 1983: 34; 2002: 79). Female and male children went to those institutions as from 5-6 years old till the tanzimat era (Akgündüz, 1986: 34; Akyüz, 1999: 144). Sources show that children in preschool age were accepted to correctional facilities and ottoman orphanage (Akyüz, 1996: 11; Oktay, 2002: 79).

Establishing pre-school education institutions in several provinces of emperorship coincided to the period before the second constitutional era. It is known that private preschool organizations were opened in some of the provinces before the date of July 23, 1980 (Oktay, 2002: 79-80). However, the 
organizational institution of preschools in Ottoman Empire period took place in a formal education system based on 23,09,1913 dated Provisional Primary Education Law (Koçer, 1995: 21).3rd, 4th and 5th articles of related law ordered to be established preschools everywhere in the country (Edis, 1946: 5-6).

A regulation was prepared for preschools that are characterized as institutions which service mental and physical development of children in 4-7 age group (Koçer, 1995: 21; Akyüz, 1996: 12; Oktay, 2002: 81) Regulation on Preschools was published in 1915 after 1912-13 dated Balkan wars. The number of preschools and nursery classes increased after this related regulation (Unat, 1944, 27; Koçer, 1995: 21; Akyüz, 1996: 14; Oktay, 2002: 83).

Much as there were made efforts to develop pre-school education in the last years of the Ottoman empire, those efforts remained incapable because of political, social and economic disasters and problems of the First World War (Oktay, 2002: 83).Since the conditions of the country in foundation years of the republic necessitated to be given priority to primary education, a significant part of resources was directed to schooling and development of schooling. 25 October 1925 dated ministerial view relating to shifting each kind of priority to primary education was reported to provinces (Oktay, 2002: 83).

Two-year kindergarten teaching school was established in Ankara in 1927 as a result of initiatives in Ankara and İzmir in 1926. This school was transferred to Çapa Female Teacher School in 1930-31 academic year. Meanwhile, 29 January 1930 dated Regulation expressed that preschools and nursery classes would not be established anymore; existing budget would be directed to primary education (Ergin, 1977: 212; UNESCO, 1977: 42; Öz, 1983: 240; Oktay, 1983: 16; Meydan, 1984: 11; Koçer, 1995: 22; Akyüz, 1996: 16).

However, with reference to the instruction of Ministry, preschools could be established in case of mothers have nobody to entrustment their children. It is seen that nursery-schools were opened in İstanbul and some of the big cities by municipalities and institutions based on 1930 dated Municipal Law, 1593 numbered Public Health Law in Turkey, 1936 dated Labor code (Koçer, 1995: 22; Oktay, 2002: 84).

There were recommendations based on works arising from legal requirements toward establishing preschools by public and private institutions in the 1940s. According to 4th National Education Council, there is a need for benefiting from various methods to be applied democratic education in the family. 1952 dated "Preschools Program and Regulation" and "Provisional Regulation on Teacher Training for Kindergartens" emphasized the significance of pre-school education. 5th National Education Council in 1953 mentioned that required aid and support will be provided for establishing pre-school 
education institutions (Özalp, 1997: 264-267; Levent, 1982: 429; Koçer, 1995: 22-23; Başaran, 1996: 74; Oktay, 2002: 84).

Turkish Education National Committee" was established in 1958 to determine the position of the Turkish Education System in the international arena. This committee published "Turkish Education National Committee Report" on July 18, 1959, and submitted to Ministry of National Education. It was stated in related report that Preschools were opened by state, local administrations and municipalities before children start to the primary education in reviewed foreign countries; children who are 5 years old are inserted in compulsory education age by this application; preschools are intensely constituted in countries where industry and agriculture developed (Turkish Education National Committee Report, 1959: 4-39; Öz, 1983: 241).

Law on Primary Education and Training" came into force on January 5,1961 . While the 6th article of related law specified primary education institutions, pre-school education institutions are in an optional part of the same article. The 13th article of the same law mentioned that "children who do not reach compulsory education age are trained in preschool education institutions. "National Education Planning Board" was constituted to spread the system of education in 10 years on January 29, 1961. Primary Education Committee prepared "Primary Education Committee Report and 10-year Plan" as a result of 6-weeks effort. It was offered in a related plan that Government Grant should be provided to spread and develop preschools; nursery classes should be opened in insufficient environments; private kindergartens ought to be established for children who need private training. 1961 constitution act brought provisions that obliged to be protected children by the parents and educated the citizens (50th art.) (T.R. Official Gazette, 10705, June 1962: 3; 10859, July 1961: 2-14; Koçer, 1995: 23; Poyraz, 2001: 13; Tekışık, 1971: 10; Öz, 1983: 242-243; Ural, 1986: 15; Meydan, 1984: 11; Yılmaz, 2003: 13; Yangın, 1991: 10; Başaran, 1996: 74; Adem, 1993: 168-169; Kantarcıoğlu, 1993: 10; Akyüz, 1997, p. 178).

20 primary school teachers were assigned for nursery classes in 10 provinces in the 1961-62 academic year. On-the-job training courses were opened for teachers in September 1961; afterward, those teachers went "preschool education" seminar to Italy (Poyraz, 2001: 13)

Regulation on Nursery Classes and Preschools" was published within the frame of required legislative arrangements of 7th National Education Council in 1962 (5-15 February). Department of Child Development and Education was opened in 3-years Girls' Vocational Schools to raise preschool teachers. This department was strengthened by formation lessons besides professional 
training. Again, the same department made a branch that raises teachers for pre-school education institutions by 11,04,1964 dated and 120 numbered Turkish Education Board Decision. "Application Preschools" were constituted within girls' technical and vocational high schools in the same years (MNE Journal of Notices, C: 25, June 1962: 1213; Yıldır, 1991: 15; Meydan, 1984: 20; Poyraz, 2001: 13).

Duration of programs of primary education teachers increased 4 years in line with 8th National Education Council decisions toward reorganizing the system in secondary education and passing to higher education in 1970 (28 September-3 October). Courses relating to pre-school education were inserted in curriculums (Yılmaz, 1999: 18; Poyraz, 2001: 13; Kantarcıoğlu, 1993: 14).

Pre-school education took place in the general structure of Turkish National Education System based on 1973 dated and 1739 numbered "National Education Basic Law" (19th art.); purposes and duties of pre-school education were determined (20th article); conditions of constituting of pre-school education institutions were mentioned (21st art.). An obligation was imposed for all teachers to graduate from higher education (Öz, 1983: 246; Koçer, 1995: 25; Poyraz, 2001: 13; Yılmaz, 2003:14).

It was mentioned in 9th National Education Council in (24 June-4 July) 1974 that pre-school education institutions can be constituted as independent preschools; moreover, pre-school education institutions can also be constituted as nursery classes that are attached to the first degree of primary education organizations and application classes attached to other educational institutions (Oktay, 2003: 85).

Preschool Branch" was consisted in General Directorate of Primary Education by March 16, 1977, dated and 16927 numbered ministerial approval. Services relating to pre-school education was conducted by this branch (Meydan, 1984: 20). On-the-job training programs about teachers in preschools and nursery classes were declared by November 2, 1977, dated and 61525 numbered circular letter. The significance of pre-school education at national and international level was verbalized by "Pre-school Education Seminar" organized by UNESCO in 20-22 March 1978. This related scientific meeting displayed the expected effect; Ministry of National Education decided to be developed pre-school education as a project. This project was conducted by Administrative Sciences and Application Institute of Boğaziçi University. A publication with 6 scientific reports was prepared by Boğaziçi University group and also by the help of Hacettepe University, Social Services Academy, Ministry of Education, Primary Schools and Directorates of Girls' Technical Education. "Pre-school Education" pilot scheme started in 29 provinces by September 
12, 1979, dated and 47742 circular letters; "Educator Training Seminar" was organized (Öz, 1983: 247-248; Yangın, 1991: 10-11; Meydan, 1984: 20).

1979 International Child Year brought forward child issue again in our country. Several articles including education were published during the year 1979; especially two important scientific meetings were held. One of the meetings was the national meeting organized by International Child Year National Committee in 1979; more than seventy scientific declarations was submitted. Another meeting was the scientific meeting about "Child and Education"' organized by Turkish Education Association. All these works and historical developments increased the interest towards relating feeling (T.E.D., 1980: 7; Öz, 1983: 249).

After September 12, 1980 "Basic Education Working Group" from 41 working groups prepared a Proposed Law on Preschool and Basic Education Institutions. Pre-school education policy was mentioned in "Educational Policy Working Group" (MNE, 1982: 12-13; DPT, 1982: 51-59; Öz, 1983: 251-252).

With reference to the decisions of 10th National Education Council (2326 June) in 1981"Nursery classes need to be discussed at a level that can be obliged in time; pre-school education classes should be popularized so as to be concentrated on Turkish education in rural regions; game and education materials need to be developed; observation tools should be improved for children in pre-school age (MNE, 1982: 13-21; Öz, 1983: 253; Meydan, 1984: 21).

According to the 10th National Education Council Decisions Application Plan, an expert commission that is composed of professionals would be constituted to maintain pre-school education works. Related expertise commission was constituted by 19 January 1982 dated and 2126 numbered ministerial approval. Expertise commission demanded the works of Ankara University, Middle East Technical University Children's Houses Foundation relating to education; information collected was organized by investigating. It was asked to be opened nursery classes by using all opportunities as from 1982-1983 academic year by the 21 January 1982 dated and 2455 numbered circular letter. 427 nursery classes and 1 preschool were established as the result of the circular letter (MNE, 1982: 22-23; Meydan, 1984: 21; Oktay, 2002: 85).

Pre-school education institutions took place in 41st article of the 1982 constitution act. There is the provision called "State takes required precautions to provide welfare and peace of the family and teach family planning (Turkish Constitution, 1982, art. 41).Plannings were completed by sending the forms relating to on-the-job training of teachers for preschools and nursery classes 
by March 14, 1983, dated and 7186 numbered circular letter (1983/65). 150 teachers took on-the-job training in July and August in 1983. Nursery teachers who stayed out of the planning took on-the-job training between the dates of 5-15 September 1983 in 67 city centers and country towns (MNE, 1983: 47; Meydan, 1984: 24).

There was found a local solution for teacher requirement by bringing $12,10,1983$ dated and 2917 numbered provision called "If there is not enough highly educated teacher for preschools and nursery classes, individuals who showed success in courses of Ministry of National Sciences can be assigned as temporary teachers as from the year of 1984 (T.R. Official Gazette, 18044, October 1983: 8; İyigün, 1983: 228-229).

With reference to the 3rd article of 2828 numbered Law on Social Services and Child Protection Institution "Daily children's home are responsible for caring children; protecting and improving mental and physical of children". Nursery services were inserted in duties of the Ministry of Health (MNE, 2000, V: I: 249).According to the 9th article of December 14, 1983, dated and 18251 numbered delegated legislation "General Directorate of Primary Education is responsible for conducting all service and duties about education services of preschools, primary schools, and other educational establishments". Much as it was continued to conduct preschool affairs with the cooperation of General Directorate of Girls' Technical Education (Official Gazette, 18251, December 1983: 4).

Principles, personal conditions, the tariff of fares, inspection rules, procedures and principles relating to establishment and working of daily children's home were determined by 26,12,1983 dated and 18263 numbered Regulation on Establishment and Working Principles of Daily Children's Home (T.R. Official Gazette, 18263, December 1983: 4-11).

Working groups were constituted toward being applied decisions of 10th Council by December 28, 1983, dated and 48399 numbered undersecretariat's orders; related groups were made a single commission in terms of productivity (Öz, 1983, p. 254). March 10, 1984, dated and 18337 numbered Regulation on Preschools and Nursery Classes mentioned provisions relating priorities about establishing pre-school education establishments (Meydan, 1984: 24).

600 preschool and nursery teachers in Trabzon, Ankara, Aydın and Samsun received on-the-job training between the dates of 9 and 20 July in 1984; entirely 300 primary school head teachers whose 159 were in Gaziantep and 150 were in Kırklareli Provinces received on-the-job training; entirely 1050 teachers and 300 school managers in Samsun, Amasya, and Ankara received on-the-job training between the dates of July 23 and August 3 in 1984. 
Development works for pre-school education continued in the years of 1985, 1986 and 87. 2265 nursery classes were established in 1985; 2835 nursery classes were planned to be established in 1986. 321 nursery classes were constituted in 1987 as the result of the efforts of General Directorate of Girls' Technical Education and Department of Private Education Institutions (MEGSB, 1987: 72).

With reference to the 8th article of 222 numbered Primary Education and Training Law, preschool and nursery class teachers who graduated from secondary education started to an associate degree program (Gazi-Anadolu and Marmara). 4000 teachers received associate degree program till the end of 1991.

12nd National Education Council described preschool teaching as 2-year higher education level relating to Turkish Education System, Higher Education and Teacher Training Programs in (18-22 June) 1988. High-school graduates were assigned as teacher assistants or educator after pedagogic formation. It was decided to develop pre-school education programs so as to meet the deficiencies of family environment (MEGSB, 12nd National Education Council, 1988: 193-194; Oktay, 2002: 85).

Preschool Education Program" came into force by March 16, 1989, dated and 38 numbered Turkish Education Board Council. Legislation construction and equipment works were accelerated by 25 September 1989 dated and 17192 numbered circular letter (MNE Execution plan, 1989: 2; Yangın, 1991: 11; Akyol, 1990: 6).The number of preschool and nursery classes increased to 3625; the number of students increased to 113.383; the number of teachers increased to 6624 in early 1990-1991. 530 preschool teachers were assigned in 1991. 10 primary education inspectors were taken from the department of preschool education (Yangın, 1991:12).

General Directorate of Preschool Education was constituted in 1992 by 3797 numbered Law on the Organization and Duties of the Ministry of National Education (MNE, 1992: 3).14th National Education Council prioritized preschool education differ from other councils in (27-29 September) 1993. According to the decisions of the related council, preschool education was prioritized; preschool education legislation and pre-school education models sub-commission were constituted to continue to application works (MNE 14th National Education Council, Commission Report, 1993: 2-37; Oktay, 2002: 8586).

In the light of development and innovations in education, September 21, 1994, dated and 590 numbered decision of Turkish Education Board was accepted to form a basis for education program and support developments of 
pre-school age children in all fields as from the years of 1994 and 1995. It is seen that subjects were thought as tools to bring prepared behaviors; a master schedule was improved based on child-centered active learning principle (MNE, 1994: 2; Oktay, 1999: 90).Although the institutions under different names in pre-school education field service toward the same purpose, Government Program and Ministry of National Education Executive Plan gave place for the provision called "Regulations on Pre-School Education" to remove the difference and untidiness in education programs (Yılmaz, 1994: 9).

15th National Education Council gave importance to the issue of "increasing compulsory education to 8 years" in (13-17 May) 1996. There was taken a significant decision about the need of being inserted preschool education in the scope of compulsory education. The same council decided on issues about popularizing family participation programs and parent schools (MNE, 1995: 79; Oktay, 2002: 86). Regulation on Preschool Education Institutions" came into force by publishing on 21 July 1996 dated and 22703 numbered official gazette (T.R. Official Gazette, 22703, July 1996: 5-12).

1475 numbered Regulation on Principles and Procedures for the Establishment of the Institutions under the Labor Law" was brought into force by preparing the officials of MNR Ministry of Labor and Social Security (Uluğbay, 1998: 34).306 numbered Law went into operation by publishing on August 18, 1997, dated and 23084 numbered Official Gazette. 8-years compulsory education started as from 1997-98 academic year as required by related law. 30 independent preschools and 157 nursery classes were established in 1998. 1277 temporary teachers were assigned in pre-school education institutions that have teacher need. It was tried to achieve preschool education goals by the collaboration of Turkish Radio and Television Association, nongovernmental organizations, foundations, private institutions (MNE-APKKB, 1998: 47; Uluğbay, 1998: 35-36).

February 26, 2002, dated regulation on Pre-school Education Institutions reorganized the rules on the establishment, management, education and working of public and private pre-school education institutions of Ministry of National Education (MNE Journal of Notices, 2534, March 2002: 146-162). It was determined in findings obtained from studies relating to "Pre-school Education Programs" that teachers could not sufficiently focus on required goals and behaviors. Modern program development approaches were updated in light of previous experiences and accepted by 31.5.2002 dated and 270 numbered decision of Turkish Education Board. Related updating came into force by being declared June 2002-2537 dated Journal of Notices (MNE, Journal of Notices, 2537, June 2002: 413-427; Yılmaz, 2003: 17). 
Pre-school education reached $11 \%$ in Turkey as from 2001-2002 academic year. Education opportunity was provided for 289.118 children by 415 preschools that were newly opened in a 2001-2002 academic year. There was seen $1431 \%$ increase in a number of public preschools; $489 \%$ in a number of public nursery classes; $289 \%$ in the number of children; $250 \%$ increase in a number of teachers between the years of 1992 and 2002. Much as the increase in a number of the institution, student and teacher are remarkable, the related increase is far removed from meeting the real need of age population.

The works to improve the quality of pre-school education in Turkey has been continued by the cooperation of the Ministry and the Nongovernmental organizations by benefiting from models such as multi-purpose preschool education centers that aim to minimize the educational differences between families and provide equality in opportunity (Oktay, 2002: 90-94; Yılmaz, 2003:14-15)

However, being adopted the importance of the issue and popularized preschool education could not develop in parallel with the rate in other education levels. Pre-school education is at a low level by $11 \%$ schooling rate. This rate can increase to $100 \%$ in Western Countries.

It was started to be raised teachers for pre-school education institutions by establishing the Department of Preschool Teachership in Atatürk University Faculty of Education and Marmara University as from 1987.This related institution still services as the Department of Preschool Teaching in Atatürk University Faculty of Education and Marmara University.There emerged institutional integrity that raises teacher at every stage from the preschool to the university in Turkey as from 1991-1992 (Oktay, 1993: 76).

Accordingly, there has been provided a significant development in preschool education field. Authorities have not still reached targeted schooling rates in four and five-year plans. Almost $11 \%$ of age population could be trained despite all efforts.Being understood the importance of pre-school education plays a significant role in being conducted works by several private and government agencies (14th National Education Council, 1993: 235-236).

$92 \%$ of pre-school education institutions, $93 \%$ of students and $87 \%$ of teachers are official as from the end of 2002.

In our country, preschool education is given in public and private preschools of the Ministry of National Education; primary schools; practice classes in girls' vocational high schools; public and private kindergartens, day nurseries and nurseries of Social Services and Child Protection Institution (Commission, 1993)

General Directorate of Pre-school Education was established in by 3797 numbered Law on Organization and Duties of Ministry of National Education 
because of ever-increasing need and importance (MNE, 1992). Pre-school education as a pilot scheme in 22 provinces was inserted in the scope of compulsory education as a result of social awareness studies constituted by Ministry, Universities and related public institutions, nongovernmental organizations in the 2018-2019 academic year.

\section{Inspection of Pre-school Education in Turkey Importance of Inspection in Pre-school Education}

Inspection is utilized to determine the current situation about our educational goals. We can find the relations between goals and present state via inspection. New plans are developed if there are deviations.Gains of the system of education returns to the society as qualified manpower. The system of education has a significant role in forming human resources direct the future of society. The system of education is affected by all social institutions; education affects human development because of its social features.

Education organization needs to fulfill these significant activities in communal living. Achieving the goals is one of the important conditions for organizations to survive. Achieving the goals are based on ideally using all the sources. Organization employees should work by obeying the rules determined. Observing and inspecting the studies in organizations is the condition for productivity. Inspection subsystem is a department that continuously deals with inspection of works (Cengiz, 1991: 95).Educational institutions that are the social institutions are obliged to show their activities to society. An institution which do not fulfill their social duties and also the organizations whose effectiveness is not trusted lose their position in time. Quality of education needs to be measured and evaluated by objective methods (Turgut, 1985: 103).

Education activities are detailedly analyzed during the inspection. In the light of existing information, it is tried to determine whether the works are effective to provide the desired productivity. Criteria in assessment are the target behaviors determined. Realization level of these behaviors is found. The consistency of challenges in achieving the goals relating to realization level of goals is researched. Methods are improved about difficulty levels of challenges in application. Data are submitted to decision making centers at the end of the inspection system. Inspection system has a significant function to be provided proper studies to the goals of the system of education. The chief goal of the inspection as an instrument of modern management is to increase the productivity of the organization (Açıkalın, 1992: 148).

Education is the work that evaluating all the factors affect learning and preparing environment conditions for more effective teaching and learning environment conditions. The primary aim of the school is to actualize learning. 
All the activities in school are directly or indirectly about realizing learning. Inspection is a factor that aims to realize learning (Aydın, 1984: 11-12).

\section{Legal Foundations of Pre-School Education}

All institutions and organizations in the Republic of Turkey that is the state of law endeavor to conduct their activities based on their rights and obligations within the legal framework. Inspection subsystem that is one of the most important and irreplaceable subsystems of education performs its duties based on the constitution, regulation, and circular letters.

The purpose of a 53rd article of Regulation on MNE Presidency of Primary School Inspectors is as follows;

Establishing presidency of primary education inspectors; providing related presidencies to work; determining required qualifications for candidates of inspectors and inspector assistants; specifying assignment and evaluation conditions of related conditions; increasing effectiveness and productivity in inspection and counseling services.

Moreover, related law described the responsibilities of personnel of presidency of primary school educators; duty, power, and responsibilities of primary education inspectors and inspector assistants; assignment, selection and raising conditions of inspectors and inspector assistants; establishment and duties of presidencies of primary education inspectors (MNE, 2000: 13691389).

Descriptions in related law are as follows; Inspector: Primary education inspector; Inspector assistant: Primary education inspector assistant; Leader; director, head assistant of director; Institution; public and private schools and other service units; Inspection area: the location of inspection groups of the province (MNE, 2000: 1370).

d sub-article of 42 nd article of the same regulation defined duty and powers of inspectors as counseling and on-the-job training; inspection and assessment (MNE, 2000: 1378). With reference to the same article of the related regulation, pre-school education institutions and application classes are inspected by the primary education inspectors.

Within this framework, the purpose of counseling and inspection is specified in the 5th article of the January 01, 2001 dated and 2521 numbered Regulation on MNE Presidencies of Primary Education Inspectors Counseling and Inspection (MNE, Journal of Notices., 2521, January 2001: 30).

Inspection activities in all pre-school education institutions of the Ministry of National Education are conducted as inspection activities, executive inspection, teacher inspection, seminar, and course inspection. 


\section{Inspection Applications with Group in Pre-school Education Institutions}

Purpose of working with a group is to obtain a group product and benefit from the product at the same time. Inspector has four functions in group inspection as leadership, observation, counseling, and spectatorship (Taymaz, 1993: 92).

The 35th article of Regulation on MNE Primary Education Inspectors mentioned that the inspection activities are performed with a group inspection. According to the same regulation, inspection regions and groups are divided into inspection areas by considering the number of school administrators and teachers by the opinion of the provincial director of national education and also the approval of governorship. Inspection groups that are composed of a sufficient number of inspector and inspector assistant are constituted. Inspectors and inspector assistants are balancedly distributed to the inspection groups by the opinion of the provincial director of national education and also the approval of governorship 15 days before the start of the academic year. It is essential to perform a duty in the same inspection region for two years; however, the inspection region can be changed before two years force majeure (MNE, 2000: 1377).

Within this scope, inspection responsibility is taken under the scope of directors of schools in 2015. These related activities were conducted by public officials under the titles of primary education inspector and education inspector as from the first years of Republic

It is mentioned in the 17th article of 652 numbered Delegated Legislation on Organizations and Duties of Ministry of National Education that Education inspectors are conducted an inspection, investigation, and research works by an approach that avoids irregularities in issues within the duty area of the Ministry

It is aimed by August 20, 2017, dated and 30160 numbered Instruction on Duty, Power, Responsibility and Working Principles of Presidency of Supervisory Board to provide a consensus in practice about pre-school education as from 2017-2018 academic year. Current legal arrangements are considered in inspections.

All institutions and organizations in the Republic of Turkey that is the state of law endeavor to conduct their activities based on their rights and obligations within the legal framework. Inspection subsystem that is one of the most important and irreplaceable subsystems of education performs its duties based on the constitution, regulation, and circular letters. 


\section{Notes}

$\left(^{*}\right) \quad$ Dr. Öğrt. Üy., Sakarya Üniversitesi Eğitim Fakültesi.

E-posta: tcakir@sau.edu.tr

\section{References}

Akgündüz, H., (1986). Primary School. Ankara: Kadıoğlu Publishing House.

Akyol, A., (1990). Education in the Grand National Assembly of Turkey. Ankara: Course Equipments Center Publishing House.

(1994). History of Turkish Education. İstanbul: Kültür College Publications.

Akyüz, Y., (1997). History of Establishment and Development of Kindergartens in Turkey. 1st National Children's Culture Congress, A.U. Child Culture Research and Application Center Publ., Ankara.

Aydın, M., (1982). Role Perceptions of Primary School Inspectors (Unpublished Research Report). Ankara.

Başaran, i.E., (1996). Education Management. Ankara: Gül Publishing House.

Cengiz, C., (1992). Training of Ministry of National Education Inspectors and Improving Inspection. İstanbul: Milli Eğitim Publishing House.

Edis, B., (1946). Annotative Temporary Primary Education Law. İstanbul: Milli Eğitim Publishing House.

Ergin, O., (1977). History of Turkish Education. C. 1-2, İstanbul: Eser Publishing House.

Gözübüyük, Ş., (1999).Management Law. Ankara: Gül Publishing House.

Kantarcıŏlu, S., (1993). Kindergarten Organization. Teacher Books: 94, İstanbul: Milli Eğitim Publishing House.

Koçer, H. A., (1995). Emergence and Development of Modern Education in Turkey. ResearchReview Series, İstanbul: Milli Eğitim Publishing House.

Levent, E., (1982). "Pre-school education" State Planning Organization, Education Sector Report. Ankara: Başbakanlık Publishing House.

Meydan, S., (1984) Pre-school Education Activities. Ya-pa 1. Seminar on Pre-School Education and Dissemination of Pre-School Education 1984. İstanbul: Ya-pa Publications.

Ministry of National Education, Youth and Sports (1986). Official Preschools and Kindergartens Research. MEGSB Official Preschools and Kindergartens Research, Edition Number. 152, Ankara: Publishing House.

Ministry of National Education (1949). Fourth Education Council. İstanbul: Maarif Publishing House.

- (1953). Fifth Education Council. İstanbul: Milli Eğitim Publishing House.

(1962). Seventh Education Council. Ankara: Milli Eğitim Publishing House.

MEB

(1966). Schoolchildren in the Netherlands. Teacher's Books: 120, (Translator: Dr.Yusuf Tunca), İstanbul: Milli Eğitim Publishing House.

(1971). Eight Education Council. Ankara: Milli Eğitim Publishing House

(1975). Ninth Education Council. İstanbul: Milli Eğitim Publishing House.

(1982). Ministry of National Education White Book. Ankara: Milli Eğitim Publishing House.

(1982). Tenth Education Council. Ankara: Milli Eğitim Publishing House. 
Ministry of National Education (1983). Education in the Republican Period. Series of Science and Cultural Works No. 1, İstanbul: Milli Eğitim Publishing House.

(1983). Board of Education (1923-1983). Ankara: General Directorate for Apprenticeship and Non-formal Education Publishing house

(1988). Twelfth Education Council. Ankara: Milli Eğitim Publishing House.

(1992). Law on Organization and Duties of MNE. Ankara: Vocational and Technical School Publishing House.

(1993). Preschool Education Commission Report. T.T.K.B., Secretariat of the Council, İstanbul: Ya-pa Publishing House.

(1993). Fourteenth Education Council. İstanbul: Milli Eğitim Publishing House,

(1996). Education Policies of European Union Countries. Board of Education Avrupa Birliği Masası. Ankara: Milli Eğitim Publishing House.

(1996). Education Systems of European Union Member States. Foreign Relations Department. Ankara: Milli Eğitim Publishing House.

(1996). Fifteenth National Education Council. İstanbul: Milli Eğitim Publishing House.

(1997). Eight Year Uninterrupted Compulsory Education. Research Planning and Coordination Board. Ankara: Ajans Türk Publishing House

(1999). Educational Systems in the Republican Period. Foreign Relations Department. Ankara: Milli Eğitim Publishing House.

(2000). National Education Legislation. C. I, İstanbul: Milli Eğitim Publishing House.

- (2000). National Education Legislation. C. II, İstanbul: Milli Eğitim Publishing House.

(2000). National Education Legislation. C. III, İstanbul: Milli Eğitim Publishing House.

Oktay, Ayla (1983). School Maturity. İstanbul University Faculty of Literature Publications, Edition number. 3089, i̇stanbul.

(1983). Past and Present of Pre-School Education in Turkey. Journal of Education and Science, 7, Ankara.

(2002). Magic Years of Life. İstanbul: Epsilon Publications.

Öz, M.F., (1983). "Pre-school education" Education in the Republican Period. Series of Science and Cultural Works, İstanbul: Milli Eğitim Publishing House.

Özalp, R.; Ataünal, A., (1977). Organization Board in Turkish National Education System. İstanbul.

Pazarcı, Ş., (1996). State Civil Servants Law and Judgment Decisions. Ankara: Adalet Publishing House Co.Ltd

Poyraz, H., (2001). Principles and Methods of Pre-School Education. Ankara: Anı Publications.

T.R. Official Gazette (10705). Primary Education Law (222 S.K.). 12 Ocak 1961. Ankara: Başbakanlık Publishing House.

(18059). Law on Social Services and Child Protection Institution (2828 S.K.), May 27, 1983. Ankara: Başbakanlık Publishing House.

(23084). 1739; 222; 3308; 3797; 3418 Law on the Taking of Contribution to Education from Some Paper and Transactions (4306 S.K.) in 1739; 222; 3308; 3797; 3418 numbered laws, August 18, 1997. Ankara: Başbakanlık Publishing House.

Taymaz, H., (1993). Inspection: Concepts, Principles, Methods. Ankara: Pegem Publishing House.

The Constitution of the Republic of Turkey (2001). Güldağ Publishing House, İstanbul. 
